SCJR 13, no. 1 (2018): 1-14

\title{
Ernest Bloch, Richard Wagner, and the Myth of Racial Essentialism
}

\author{
AARON KLAUS \\ aarondklaus@gmail.com \\ Towson University, Towson, MD 21252
}

\section{Introduction}

Swiss-born Jewish composer Ernest Bloch's musical language is characterized by rhetorical gestures that represent a connection to his Jewish roots. Although these characteristic gestures helped him form a connection to his Jewish identity, they also connoted a sense of Jewish exoticness for the European mainstream, leading to a critical perception of his "otherness." The roots of this contradiction lie in the writings of the notoriously antisemitic German composer Richard Wagner.

Wagner articulated his antisemitic views most clearly in the infamous 1850 essay, Das Judentum in der Musik (Judaism in Music). The essay, which Wagner initially published under a pseudonym, initially had minimal impact because "Wagner's ideas ... formed part of previous anti-Jewish discourse dating back at least fifty years in German culture."1 Millington agrees that Wagner's ideas were not novel, as "the preoccupations and prejudices of 'Das Judentum' ... place it in an anti-Jewish tradition, often of otherwise impeccably liberal and humanitarian credentials, going back via Luther to the Middle Ages."2 However, when republished in 1869 at the height of Wagner's popularity as a composer (under his real name), Das Judentum quickly became a public favorite. In fact, this essay would strongly influence Nazi ideology several decades later.

Ironically, Bloch fell under the sway of mainstream Europe's obsession with racial purity early in his life. His musical encodings of Jewishness must therefore always be understood through his conception of Judaism as a race. Nevertheless, neither Wagner nor Bloch understood the complexity of defining Jewish identity, and Bloch certainly did not foresee that racial purity could be used to justify subjugating people. An examination of the evolution of Bloch's Jewish identity will thus demonstrate the moral imperative to not define others based on race.

\footnotetext{
${ }^{1}$ James Loeffler, "Richard Wagner's 'Jewish Music': Antisemitism and Aesthetics in Modern Jewish Culture," Jewish Social Studies 15, no. 2 (Winter 2009): 5.

${ }^{2}$ Barry Millington, "Wagner: (1) Richard Wagner," Grove Music Online, accessed Mar. 2, 2016, Oxford Music Online.
} 


\section{Social Background of Das Judentum in der Musik}

Prior to Das Judentum, Wagner did not exhibit anti-Jewish sentiment in any of his statements, writings, or public behavior; furthermore, the period between initial publication and republication was, in fact, marked by a relative lack of antiJewish sentiment in Germany. Thus, the circumstances of the essay illuminate the social factors surrounding the rise of antisemitism in the years immediately prior to Bloch's birth in 1880 .

Wagner most likely wrote Das Judentum because of his growing resentment towards the success of Jewish composers Felix Mendelssohn and Giacomo Meyerbeer. Desperate to distinguish himself artistically from Mendelssohn (who was one of the most prominent German composers of the time) and Meyerbeer (whose operas enjoyed consistent critical success during his lifetime), Wagner turned to their Jewish background, writing to Franz Liszt that "he nourished 'a longsuppressed anger against this Jew-business, and this anger is as necessary to my nature as bile is to the blood.",3

Wagner's decision to republish the essay was driven by "the Jewish problem [which] possessed him increasingly and ever more obsessively until his death, giving him no rest, tenaciously invading his conversations, letters, and articles, prejudice ripening into unreasoning hatred and finally settling into a diseased leitmotif." ${ }^{\text {B }}$ By the time of the republication, Wagner found an environment open to anti-Jewish sentiments, fueled by the economic downturn that began in 1873 . Popular German media spread "accusations that Jews had planned the crash to serve their conspiratorial ends, [and] that even the government of Prince Bismark had sold out to Jewish interests" - charges that "dovetailed neatly with older indictments of the Jews." ${ }^{5}$ Feeding off these sentiments, Wagner argued in his 1878 essay "Modern" that Jews were undermining German cultural and moral standards. On his perception that Jews were attempting to alienate Germans from their own culture, Wagner wrote:

"Liberal Jewry" still has "colossal" efforts to make in this direction before all the original talents of their German fellow citizens have become completely ruined. They have a long way to go before the feathers grown out of our own hides can only play word games with incomprehensible slogans, badly translated and absurd phrases, etc., or before all our musicians have assimilated the remarkable art of composing without imagination. ${ }^{6}$

\footnotetext{
${ }^{3}$ Jacob Katz, The Darker Side of Genius: Richard Wagner's Anti-Semitism (Hanover: UP of New England, 1986), 49.

${ }^{4}$ Robert W. Gutman, Richard Wagner: The Man, His Mind, and His Music (San Diego: Harncourt Brace Jovanovich, 1990), 301.

${ }^{5}$ Richard S. Levy, ed., Antisemitism in the Modern World: An Anthology of Texts (Lexington: DC Heath, 1991), 121.

${ }^{6}$ Qtd. in Levy, Antisemitism in the Modern World, 54. "Modern" originally appeared in Bayreuth Blätter, March 1878, 59-63.
} 
Wagner's fear of Jewish influence in German culture coupled with his popularity in 1878 fueled growing antisemitic sentiments among his followers. Although the concepts of Jew hatred and Judeophobia trace their roots back thousands of years, the phenomenon of antisemitism in modern Europe was new. As Richard S. Levy notes, antisemitism - a word and its abstraction that first appeared in Germany in 1879 - "is not merely emotional, it is activist. Antisemites advocate long-term activity against Jews, the enemy." Indeed, "the years 1875-79 were an incubation period for the anti-Semitic movement, which was marked by the interaction of a literary agitation against the Jews and a positive reaction on the part of the public." ${ }^{\prime 8}$ Although Wagner did not take part in this movement, his ideas inspired its followers.

Wagner was thus both part of a growing movement towards an obsession with racial essentialism - the idea that each racial group possesses an underlying essence stemming from inherent traits and abilities - and a driving force behind it. As Jews became more secularized throughout his lifetime, religiously-based anti-Jewish sentiments became more difficult to justify, which meant that Wagner's contemporaries turned to racial essentialist antisemitism. This mindset explains why people who converted from Judaism to Christianity tended to be viewed with suspicion. Wagner began to adopt this mentality in the late 1870s as well — no doubt, preceded by his earlier conception of the Jews as Stamm (tribe) in Das Judentum - but now, race could be used to refer to the Jews in particular.

\section{The Paradox of Assimilation and Implications for Jewish Composers}

In Das Judentum, Wagner articulated his belief that identity is revealed through a shared national language. Furthermore, he believed that strengthening his identity would allow him to express an eternal human reality in his art. By reaching the deepest strata of his inherent language, Wagner asserted, he would discover a human condition in which all people shared common ground. Thus, his art would be "universal" - reaching all of humanity.

However, Wagner did not believe that Jews had the ability to reach the universally human through the tribally specific, rehashing the antisemitic trope that the Jewish people "constitute a transnational category of cultural parasites, merely imitating the various cultures in which they reside." In Das Judentum, he writes:

The Jew speaks the language of the nation in which he lives from generation to generation, but he always speaks as a foreigner. ... The fact that that the Jew only speaks modern European languages as learned, not as innate, excludes him from the ability to express himself idiomatically, independently, and comfortable to his nature. A language, its expression and formation, is not the work of individuals, but of a historical common ground: only those

\footnotetext{
${ }^{7}$ Levy, Antisemitism in the Modern World, 4.

${ }^{8}$ Katz, The Darker Side of Genius, 106.

${ }^{9}$ Loeffler, "Richard Wagner's 'Jewish Music,"” 2.
} 
who have grown up unconsciously in this commonality also take part in its creations. The Jew has stood outside such commonness, lonely with his Jehovah in a fragmented, unbounded tribe, in which all development had to fail, as even the peculiar (Hebrew) language of this tribe was preserved to him only as a dead one. To truly poetize in a foreign language is impossible even for the greatest geniuses. Our whole European civilization and art have remained a foreign language for the Jew, for he did not participate in its development, and at most has viewed it with coldness, even hostility. The Jew can indulge in this art and imitate it, but cannot truly write his own poetry or create his own works of art. ${ }^{10}$

Wagner's argument that artists could only achieve universality by descending to "tribal" roots was inherently problematic for Jewish composers because he believed that they lacked a coherent ethnic identity. This problem reflected the larger paradox of Western European Jewish emancipation in the nineteenth century: while emancipation's emphasis on liberty, tolerance, and brotherhood led to equal citizenship rights for Jews, the many preceding centuries of Jewish isolation had cemented cultural barriers to integrating them into modern society. ${ }^{11}$

This paradox (which contrasts with emancipation's ultimatly less-thanaltruistic goal of assimilating Jews in the hope that their religious identity would disappear into the mainstream) forced nineteenth-century Jewish composers to demarcate their Jewish identity in their art, and as David M. Schiller notes, they accomplished this mandate "by working from both within and outside Jewish liturgical traditions." ${ }^{12}$ Composers "within," including Salomon Sulzer (18041890), Samuel Naumbourg (1817-1880), and Louis Lewandowski (1821-1894), wrote liturgical music in an assimilated, European idiom, which barred them from becoming part of the pantheon of great European composers. Concurrently, composers “outside," including Mendelssohn (1809-1847), Meyerbeer (1791-1864), and Jacques Offenbach (1819-1880) wrote European music for European audiences, thereby rejecting Jewish liturgical traditions in their art. Miles Hoffman

\footnotetext{
${ }^{10}$ Richard Wagner, "Das Judenthum in der Musik (1869)," Wikisource, Mar. 22, 2016, Accessed Jan. 26, 2018, https://de.wikisource.org/wiki/Das_Judenthum_in_der_Musik_\%281869\%29. Translation by the author.

${ }^{11}$ Jacob Katz treats the subject of Jewish emancipation in great depth. Prior to emancipation, Western European Jews lived in ghettos with cultural, political, and social autonomy, but in the nineteenth century, reformers aimed to integrate Jews into modern society, forcing the issue of assimilation. However, social norms protracted the process by which integration played out. Katz notes: "Assimilation, it is true, makes progress insofar as some Jews are coming into more intimate contact with nonJews and all Jews more and more adopt the cultural patterns of their surroundings. But, at the time, Jews also create the instruments that continue to hold them together and help them maintain a separate social identity. The conception of Jews as a congregation existing merely by virtue of a common confession of faith functioned only on the theoretical level. In reality they retained the characteristics of a subgroup in society, recognizable by its ethnic origin, its economic concentration, its comparative social isolation, and by its nonconformist minority religion." (Jacob Katz, Out of the Ghetto: The Social Background of Jewish Emancipation, 1770-1870 [Cambridge: Harvard UP, 1973], 213.)

${ }^{12}$ David M. Schiller, Bloch, Schoenberg, and Bernstein: Assimilating Jewish Music (New York: Oxford UP, 2003), 3 .
} 
suggests that Jewish composers of this era grappled with a "longing, on one hand, for distinction, separateness and 'chosenness,' and on the other hand for acceptance and belonging." He continues:

These forces are always in conflict, but in the field of music, when Jewish composers were finally free from prohibitions and persecution and began to develop their talents within the cultural mainstream, their longing for acceptance triumphed.

In a way, they were still able to remain separate, or "chosen," if only by becoming musicians, members of a rarified profession. But in the thrill of their new freedom they sought the broadest possible citizenship, choosing to write for their countries, or for the whole world, rather than the much narrower world of their co-religionists, and to define themselves by their secular accomplishments. ${ }^{13}$

Indeed, Meyerbeer and Offenbach came to be closely associated with French opera, and Mendelssohn joined the pantheon of mainstream European Romantic composers. The trend of Jewish composers choosing to eschew Jewish identity in their music continued into the late-nineteenth and early-twentieth centuriesmarked notably Gustav Mahler, who became a giant of the symphonic idiom (and who would go as far in eschewing his Jewish identity as to convert to Catholicism in 1897), and Arnold Schoenberg, who came to be defined as the pioneer of atonal music. ${ }^{14}$

Racial essentialism became increasingly prominent in European discourse throughout the nineteenth century, and by the early 1900s, "the new biological category of race had started to be used interchangeably with the historical sociopolitical concept of nation." ${ }^{15}$ This idea profoundly impacted Bloch (1880-1959), who was "perhaps the first and certainly the most successful composer to define his art as racially Jewish." ${ }^{16}$ Unlike the aforementioned composers, he wrote nonliturgical art music rooted in Judaism. However, Bloch's notion of Judaism is

\footnotetext{
${ }^{13}$ Miles Hoffman, “The Music You Won’t Hear on Rosh Hashana,” New York Times, Sept. 9, 2010, A27.

${ }^{14}$ The most famous historical precedent for the paradox of Jewish musical assimilation prior to the nineteenth century was Salamone Rossi (ca. 1570-1630), who served as a court musician in Mantua. He composed many secular works, but his most famous piece is Hashirim asher Li'Shlomo (The Songs of Solomon), a collection of Biblical psalms and hymns set in the Italian Baroque style (in their original Hebrew). His well-regarded status in the court allowed him to assimilate more easily than most Mantuan Jews - indeed, the court exempted him from having to wear the yellow badge compulsory for Jews in Mantua at the time. Nevertheless, the prohibition against Jews working for the church severely limited his potential for fame as a composer. His reasons for composing Hashirim asher Li'Shlomo are unknown, but they certainly reflect his difficult situation: as a Jew, he could never fully assimilate, yet his co-religionists probably considered him an outsider due to his privileged status.

${ }^{15}$ Klára Móricz, "Sensuous Pagans and Righteous Jews: Changing Concepts of Jewish Identity in Ernest Bloch's Jézabel and Schelomo," Journal of the American Musicological Society 54, no. 3 (Fall 2001), 439.

${ }^{16}$ Klára Móricz, Jewish Identities: Nationalism, Racism, and Utopianism in Twentieth-Century Music (Berkeley: U California P, 2008), 96.
} 
deeply entrenched in Wagnerism; Loeffler notes that in Wagnerian thought, Jews' "very otherness and 'Semitic' difference represented a potential form of cultural originality that could conceivably be turned around and reinterpreted positively."17 By asserting Jews' absence of identity, Wagner paradoxically and unwittingly bestowed upon them an identity of otherness. Furthermore, "if the Jews could reclaim their 'ceremonial music' in its original pure form, they could theoretically then create an authentic musical art." ${ }^{18}$ Thus, Bloch felt justified in reinterpreting Wagner's theory on tribalism and universality: in a Europe where racial identity was crucial, the discovery and musical application of Jewish racial authenticity became Bloch's artistic mission. Like Wagner, Bloch hoped that his racially-driven art would reach all of humanity.

Nevertheless, Bloch never grasped the futility of the endeavor to define his music by its Jewishness. This challenge lies in the very nature of diasporic existence, as Seroussi notes:

The long path of exile ... imposed on the Jews the need to accommodate to the hosting non-Jewish societies. Therefore, each community engaged in a musical dialogue with its non-Jewish surroundings, and through time many different Jewish "musics" emerged. Moreover, frequent displacements and discontinuities affecting individual Jewish communities exercised a major influence on the musical culture of each group. All in all, the active participation of Jews in the musical traditions of the surrounding societies poses a challenging scholarly question: where exactly are the limits between the music "made by Jews, for Jews, as Jews" (to quote the legendary definition of Jewish music proposed by Curt Sachs in his address to the First World Congress of Jewish Music in Paris, 1957) and the music "made by Jews, as musicians, for all listeners." 19

The music of Sulzer, Naumbourg, and Lewandowski easily passes Sachs's aphoristic litmus test. However, Sachs's criteria disregard the European musical context and traditions that shaped their compositions. The music of Mendelssohn, Meyerbeer, and Offenbach was certainly "made by Jews, as musicians, for all listeners," but the extent of the influence of their Jewish birth on their music is impossible to delineate. ${ }^{20}$ Bloch is unique because he outwardly defined his music as Jewish, yet became increasingly estranged from the Jewish community throughout his life. While composing his Sacred Service, for instance, he wrote to Ada Clement and Lillian Hodgehead, co-directors of the San Francisco Conserva-

\footnotetext{
${ }^{17}$ Loeffler, "Richard Wagner's 'Jewish Music,"” 7.

${ }^{18}$ Loeffler, "Richard Wagner's 'Jewish Music,"” 9.

${ }^{19}$ Edwin Seroussi, "Jewish music, §I: Introduction," Grove Music Online, accessed Feb. 18, 2016, Oxford Music Online.

20 Jeffrey Sposato cites numerous examples of critics painting Mendelssohn's Elijah as a Jewish work. However, he argues that the libretto drafts reveal that the work is actually a New Testamentinspired piece. For further reading, see: Sposato, Jeffrey S. The Price of Assimilation: Felix Mendelssohn and the Nineteenth-Century Anti-Semitic Tradition (New York: Oxford UP, 2006).
} 
tory of Music at the time: "I do not wish it for the Jews - who will probably fight it ... not for the critics, not for the 'Tradition'! It has become a private affair between God and me." ${ }^{21}$ Ultimately, the artistic output of each of the aforementioned Jewish composers comes from a tangled web of identities and life-experiences, and a search for unifying "Jewish" qualities in their music is futile.

\section{Bloch in Europe: The Influence of Edmond Fleg and Robert Godet}

Bloch grew up in Geneva with little sense of national belonging - he studied in Geneva, Brussels, and Munich, leaving him burdened with being lost between French and German aesthetics. He rarely visited the local synagogue growing up - certainly not enough to gain any familiarity with the dynamics of the Jewish community - and therefore, he could not help but develop a conception of Judaism borne out of the Wagnerian antisemitic ideology prevalent in European society at the time.

Bloch's Symphony in C-sharp Minor premiered in 1903, receiving mixed reviews. Critics faulted the work for its lack of identifiable national character, arguing that Bloch unsuccessfully tried to combine elements of French and German aesthetics. In late 1903, Bloch went to Paris to secure a performance of the piece. He was unsuccessful in this endeavor; however, his stay in Paris led him to reconnect with his friend, French Jewish poet and historian Edmond Fleg, whom he had met in Geneva in 1901. Fleg served as the librettist of Bloch's only published opera, Macbeth, which he wrote between 1904 and 1909. Macbeth combines French-inspired whole-tone tonalities with a German-inspired plot of murder, guilt, and revenge. As was the case with his C-sharp Minor Symphony, Bloch could not escape criticism that his music represented an amalgamation of national influences. He was, as critics Romain Rolland and Henry Prunières described, "the great wandering Jew of music.,"22

During this same period, Bloch developed a close friendship with French critic Robert Godet, who "won Bloch's sympathy in 1903 by writing the only positive critique of his C\#-Minor Symphony to appear in the press." ${ }^{, 23}$ Godet is predominately known today as a friend of Claude Debussy and an early enthusiast of Modest Mussorgsky's music. Bloch began teaching him composition in 1904; soon thereafter, Godet became Bloch's spiritual guide. Godet—who, like Bloch, was trapped in the racial discourse of the time-had a vested interest in helping Bloch create specifically Jewish art (an interest that trumped his deeply-held antisemitic views, which were unbeknownst to Bloch at this point). In 1906, Godet began providing Bloch with readings about the prophets to aid in this artistic mission. These readings evidently resulted in an epiphany for Bloch, awakening his

\footnotetext{
${ }^{21}$ Qtd. in Suzanne Bloch and Irene Heskes, eds., Ernest Bloch: Creative Spirit (New York: National Jewish Welfare Board, 1976), 74.

${ }^{22}$ Qtd. in Móricz, Jewish Identities, 100.

${ }^{23}$ Móricz, "Sensuous Pagans," 447.
} 
Jewish consciousness and stimulating interest in his racial identity. He wrote to Fleg that same year:

My dear friend ... I have read the Bible-I have read fragments about Moses. And an immense sense of pride has surged within me! My entire being reverberated. It is a revelation ... I couldn't continue reading, for I was afraid ... of discovering too much of myself, of feeling everything that had gradually accumulated, glued to me, fall away in one sudden blow; of myself naked ... within the entire past which lives inside me; of standing erect as a Jew, proudly Jewish. ${ }^{24}$

Through his reading of the Bible, "Bloch envisioned a scenario in which he himself would undergo the isolation, sufferings, and final triumph of a prophet." 25 Bloch believed that the "Jewish race" had lost its voice among the nations of the world, and that by isolating himself from the Jewish community, he would be able to find that voice in his art.

In 1911, Godet referred Bloch to Deuteronomy 13:7-11, a passage that states that worshipping idols is punishable by death. Seen through his Wagnerian paradigm, Godet took this passage to mean that "assimilation is likened to idolatry, and racial purity is its repentance. ${ }^{, 26}$ Bloch did not possess the critical skills necessary to recognize the danger of such an interpretation, given his limited Jewish knowledge. Furthermore, he readily accepted Godet's antisemitic views because "he was convinced that they applied to only the "bad' contemporary Jews"27 that he observed as a child at the synagogue in Geneva. Godet would inevitably arrive at this antisemitic interpretation of Deuteronomy given his deep interest in the work of political philosopher Houston Stewart Chamberlain (1855-1927). During his time with Bloch, Godet was engaged in the massive endeavor of translating Chamberlain's Die Grundlagen des neunzehnten Jahrhunderts (Foundations of the Nineteenth Century) into French. Chamberlain envisioned human history as the history of the "Teutonic race," culminating with Wagner, whom he believed represented the true realization of the racial mission of the Teutons. ${ }^{28}$ In Foundations (a work that strongly influenced Nazi ideology), Chamberlain outlined his vision of European history as the struggle of racial forces, in which the pure Teutons and the Jews were the most antagonistic, and argued for the superiority of the Aryan race over the Jewish race. However, Godet kept the true antisemitic nature of the work hidden from Bloch for many years, only telling him that he was working on an immense collaborative project.

\footnotetext{
${ }^{24}$ Qtd. in Alexander Knapp, "The music and life of Ernest Bloch,” Jewish Quarterly 28, nos. 2-3 (1980): 27.

${ }^{25}$ Móricz, Jewish Identities, 107.

${ }^{26}$ Assaf Shelleg, Jewish Contiguities and the Soundtrack of Israeli History (New York: Oxford UP, 2014), 37.

${ }^{27}$ Móricz, Jewish Identities, 109.

${ }^{28}$ The Teutons were an ancient Germanic tribe. Today, "Teuton" can refer to a member of a people speaking a language of the Germanic branch of the Indo-European language family, especially German.
} 
That same year, following the failure of Macbeth (which only lasted for 13 performances), Bloch went to Munich to immerse himself in Wagner's music. Following a performance of Die Meistersinger, he wrote, "I was more profoundly moved than ever." ${ }^{29}$ As Móricz argues, this experience fostered Bloch's affinity to German music, leading him to believe that "Jews ... just like the Germans, were vessels of pure humanitarian ideals." ${ }^{30}$ Bloch "agreed with Wagner that Jews were deceiving themselves when they believed that they could assimilate to the people among whom they resided." ${ }^{31}$ However, he disagreed with Wagner's belief that Jews lack a coherent racial identity; rather, be believed that Jews should embrace their racial identity to become rein menschlich (purely human). To Bloch, Jewish music had the capacity to reach the deepest strata of the human experience, much as German music did, but Jews had to find their own voice. For him, this mission could not be achieved through the institutions of Judaism; rather, he tried to construct his ideal Judaism in art as a means for uniting humanity.

In 1913, Godet presented his completed translation of Foundations to Bloch. Upon reading a portion of the work, Bloch told Godet that he found Chamberlain's antisemitic ideas offensive, to which Godet responded, "what offends you today was written 15 years ago, and during this period nobody has died of it." 32 Believing that Bloch overreacted, and in the heat of an unrelated personal quarrel, Godet cut off communication when Bloch left Europe in 1916. However, Bloch could not give up their friendship, and indeed dedicated his C-sharp Minor Symphony to Godet when the work was published in 1925. In fact, Bloch would read the entirety of Foundations in 1934 and ended up agreeing with the book's antisemitic theories about Jews, arguing that "it was not the ideas but their practical application by 'smaller minds' that could turn Chamberlain's ideology into a 'terrible weapon." "33

Ultimately, Bloch's opinion of Jews did not differ much from that of Godet. The more Bloch saw himself as a creator of rein menschlich art of the "Jewish race," the more he distanced himself from Jewish audiences and critics of his music, thereby justifying his absorption of Chamberlain's and Godet's antisemitism. He would even go as far as to say in a letter to his friend Lillian Hodgehead in 1934: "The attitude of certain Jews ... towards me - and towards everything seems to justify in a good degree the actual mentality and revolt of the leaders of Germany. ${ }^{34}$ Clearly, he maintained antisemitic views throughout his life.

\section{Bloch's "Jewish Cycle"}

Bloch's work with Fleg and Godet in the 1910s led to his "Jewish cycle," a furious burst of writing inspired by Jewish themes, and his first foray into Jewish

\footnotetext{
${ }^{29}$ Qtd. in Móricz, "Sensuous Pagans," 443.

${ }^{30}$ Móricz, "Sensuous Pagans," 444.

${ }^{31}$ Móricz, Jewish Identities, 102.

${ }^{32}$ Qtd. in Móricz, Jewish Identities, 110.

${ }^{33}$ Letter to Lillian Hodgehead and Ada Clement (July 6, 1934) in Móricz, Jewish Identities, 112.

${ }^{34}$ Qtd. in Móricz, Jewish Identities, 113.
} 
music. The cycle includes the works Trois Poèmes Juifs (composed in 1913), Prélude et Deux Psaumes (1912-1914), Psaume 22 (1914), Israel Symphony (1912-16), Schelomo: Rhapsodie Hébraïque (1916), and String Quartet No. 1 ("Hebrew") (1916).

Regarding his Jewish works, Bloch would later state, "I have hearkened to an inner voice ... which seemed to come from far beyond, beyond myself and my parents, a voice which surged up in me on reading certain passages in the bible." 35 Indeed, he held the Wagnerian ideal of reaching all humanity in the deepest layers of race throughout his entire life. Ironically, however, Bloch became critically confined to the "Jewish composer" label throughout his life, ultimately barring him from the universal status he sought.

\section{First United States Period, Return to Europe, Return to America}

In 1916, Bloch moved from Europe to the United States to assume the position of conductor with Maud Allen's dance company on their tour. The tour disbanded prematurely due to dwindling audiences, and Bloch settled in New York, where he experienced continual disappointment at the fact that Jews were largely uninterested in his music; indeed, his main proponents were non-Jewish critics. Even as he began to eschew Jewish themes in his music (as in the orchestral works America (1926), dedicated to his new home, and Helvetia (1929), dedicated to his birth home), the "Jewish composer" image stuck with him. Still, he maintained the goal of achieving universality. This goal brought him back to Switzerland in 1930, where he composed what is perhaps his most famous piece, Avodath Hakodesh (Sacred Service), a setting of the Jewish Sabbath morning service for orchestra, chorus, and baritone. ${ }^{36}$ His move was made possible by wealthy patrons Rosa and Jacob Stern, who established a fund at the University of California, Berkeley to support Bloch for ten years while he devoted himself entirely to composition. The terms of the fund stipulated that after those ten years, Bloch was to return to Berkeley as a professor.

Avodath Hakodesh is unsuitable for liturgical use because the text of the piece differs in form and emphasis from what would be used in a congregational prayer service and omits important sections, such as the reading of the Torah and the Kaddish. ${ }^{37}$ Instead, Bloch envisioned Avodath Hakodesh as a universal

\footnotetext{
${ }^{35}$ Avraham Soltes, "Ernest Bloch Has Said," in The Music of Ernest Bloch: A Program Manual, ed. National Jewish Music Council, 13.

${ }^{36}$ The text for Avodath Hakodesh is found in The Union Prayer-Book for Jewish Worship (Cincinnati: Central Conference of American Rabbis, 1922), 64-129.

${ }^{37}$ Typically, congregations read a section from the Torah (the five books of Moses) weekly on Sabbath mornings. Despite the centrality of the Torah reading in the morning service, Bloch excluded this section from Avodath Hakodesh because the reading changes from week to week, so including this part would have necessitated that he choose one particular reading to set to music. The Kaddish is a prayer of praise and affirmation, which Jews recite near the end of the service to commemorate a recent death of a loved one and on the anniversaries of their loved ones' deaths. Bloch excluded this prayer because a musical setting would interfere with the important religious obligation for mourners to recite it.
} 
"mass," meant for all humanity; indeed, the piece espouses the Wagnerian ideal of the oratorio as total art-work. In 1934, Bloch said of Avodath Hakodesh: "I believe ... my Sacred Service may be an answer to the accusations of Chamberlain ... for its Judaism is not that of the Ghetto but that of the prophets - messianic and universal." 38 Despite Bloch's universalistic aspirations with Avodath Hakodesh, the piece engendered continued race-inspired criticism. As Móricz notes: "Considered by both Jews and non-Jews as deeply flawed for what was seen as diluted racial expression, the Sacred Service demonstrated that however scientifically untenable, race remained a strong enough cultural factor to hinder Bloch's universal claims." 39 Much to Bloch's disappointment, he could not achieve universality through his assumed racial background that he expressed in Avodath Hakodesh.

With war in Europe imminent, Bloch moved back to the United States in December 1938. In accordance with the terms of the Stern fund, he became a professor at Berkeley. In 1941, while Bloch was driving from Berkeley to Portland, flooded roads forced him to stop, and he decided to spend the night in the remote and picturesque coastal resort village of Agate Beach, Oregon. He fell in love with the town so much that he bought a house there. Bloch became somewhat of a recluse in his final years, able to take inspiration from the picturesque environment around him.

Figure 1 Ernest Bloch's Agate Beach house

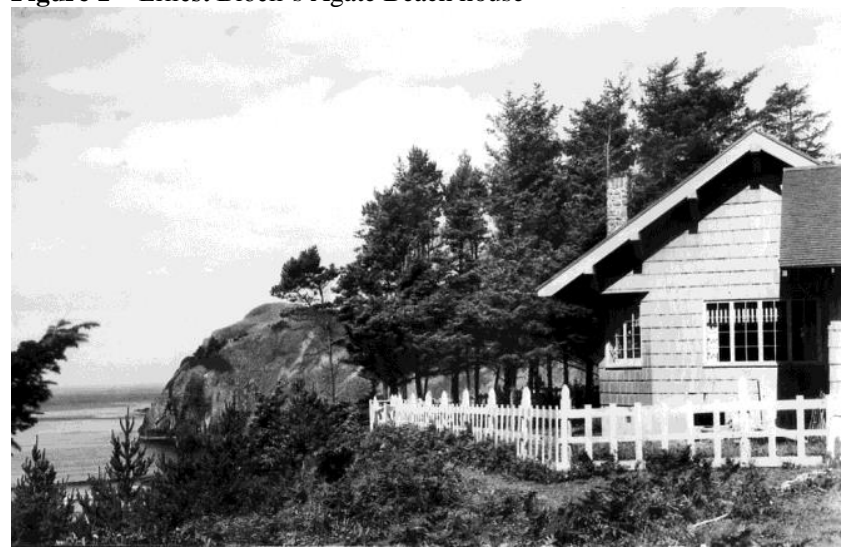

Source: David Stabler, "50 years after composer Ernest Bloch's death, Oregon celebrates his life and works," Oregon Live, July 13, 2009,

http://www.oregonlive.com/performance/index.ssf/2009/07/50_years_after_composer_ernest.html.

He would continue to teach at Berkeley until 1952 - after which, freed from his teaching responsibilities and in an environment where he could work with little interaction with the outside world, Bloch's compositional output was prolific. His

\footnotetext{
${ }^{38}$ Qtd. in Olin Downes, "Bloch, Composer, Here to Conduct," New York Times, Mar. 27, 1934.

${ }^{39}$ Móricz, Jewish Identities, 154.
} 
Jewish works from this period include Symphony for Trombone and Orchestra and Proclamation.

\section{Was Bloch a "Self-hating Jew"?}

Bloch's encounters with antisemitism via Wagner, Chamberlain, and Godet engender the question of how much he assimilated those antisemitic beliefs. Further underscoring the issue, he stated the following in 1934, suggesting that he internalized many of the negative perceptions of his non-Jewish contemporaries, as many other assimilated European Jews of his era did:

I greatly respect Hitler's sincerity. He believes wholly and disinterestedly in what he is doing. He is a fanatic, if you will, on fire with his cause, but certainly not an opportunist making political capital. I do not think he is right. But to label him and his movement merely as anti-Jewish is inaccurate. ${ }^{40}$

This troubling quote suggests that Bloch had indeed absorbed Chamberlain's antisemitic convictions, and that he was therefore a "self-hating Jew." Theodor Lessing was likely the first to coin the term "Jewish self-hatred," in his 1930 book by that title (Der Jüdische Selbsthaß). Kurt Lewin argued in his 1941 essay, "Self-Hatred Among Jews," that self-hatred exists when a minority group contains members that "are kept inside [the group] not by their own needs, but by forces which are imposed upon them." ${ }^{41}$ However, Bloch's prophetic vision of himself shows that he in fact thought quite highly of his Jewish roots. Furthermore, he tended to direct his criticisms of Jews towards what he perceived to be their lack of understanding of his artistic mission, not towards their Jewish selfidentification. Judaism was central to this mission-which elucidates why, unlike Mahler, Bloch remained Jewish throughout his lifetime.

Although Bloch espoused antisemitic views, Móricz argues that these views were "fueled by his anxiety about Jewish reception of his works," and not by "acceptance of gentile society's negative opinion of him as a Jew." " Ultimately, Bloch's relationship with Judaism was too complex for the term "self-hatred" to be meaningful. His grandiose ideas regarding what Judaism should be created a barrier between him and the rest of the Jewish world — an outlook that resulted in feelings of anxiety and insecurity manifesting themselves as antisemitism. Furthermore, this outlook evolved independently of which continent he lived on and independently of the Holocaust.

\footnotetext{
${ }^{40}$ Downes, "Bloch, Composer, Here to Conduct," 1934.

${ }^{41}$ Kurt Lewin, "Self-Hatred Among Jews," in Resolving Social Conflicts: Selected Papers on Group Dynamics, ed. Gertrud W. Lewin (Ann Arbor: Harper \& Brothers, 1948), 192.

${ }^{42}$ Klára Móricz, "Sealed Documents and Open Lives: Ernest Bloch's Private Correspondence," Notes 62, no 1 (2005), 78.
} 


\section{Conclusion: The Seductiveness of Racial Thought}

As Móricz notes, "racial theory often helped nations rise from the degrading feeling of political and economic inferiority to a sense of racial superiority. ... Bloch was only one of many artists and critics who had been trapped in the seductive discourse of race." ${ }^{43}$ Indeed, he searched for Jewish characteristics in music because throughout much of his adult life because he was seduced by the human instinct for kinship and the longing for Jewish self-affirmation and pride. However, this search has the potential to be malignant in the wrong hands, as was the case for Jewish author and composer Max Brod (1884-1968).

In 1916, writing about the music of Mahler, Brod argued:

From a German point of view, [his music] seems incoherent, lacking in style, informal, even bizarre, cutting, cynical, too soft, and too harsh ... yet, taking into account Mahler's Jewish soul, immediately the picture changes, form and content are correct, nothing is overbearing, and nothing is exaggerated. By the same token, if we take Heine not as a German lyric poet, Mendelssohn not as a classic of German music, Meyerbeer not as an Italian opera composer, and Offenbach not as a Parisian urchin, but all four as great sons of the Jewish people ... they become clearer, more straightforward, and simpler. $" 44$

However, in the 1940 edition of the Nazi encyclopedia Lexikon der Juden in der Musik, the authors argue that Brod's claims show that Mahler "could not free himself of his racial determination" ${ }^{45}$ no matter how hard he tried to do so. Brod attempted to support his view in 1951 in his book "Israel's Music" by pinpointing Jewish characteristics in Mahler's compositions, but the characteristics he findsmarch-rhythms, melodic lines fluctuating between major and minor, and melodies that start low and suddenly jump high ${ }^{46}$ - are too general to be truly indicative of Judaism. Móricz explains: "By emphasizing the unconscious, Brod created not only the perfect shelter for gathering composers of Jewish origin under one roof, but also the perfect prison from which there was no escape. ${ }^{, 47}$ For Bloch and his contemporary coreligionists, the "Jewish composer" label was uplifting and satisfying yet confining and ultimately damning.

Bloch fell to the seductiveness of this label because he falsely equated racial essentialism with identity. Those who study Bloch's music, and Jewish music in general, must remember to show "concern for Jewish experiences rather than for

\footnotetext{
${ }^{43}$ Móricz, Jewish Identities, 99.

${ }^{44}$ Max Brod, "Jüdische Volksmelodien," Der Jude 1, no. 5 (1916), 345. Translation by the author.

${ }^{45}$ Qtd. in Klára Móricz, Jewish Nationalism in Twentieth-Century Art Music, Ph.D. dissertation, U California, Berkeley, 1999 (Ann Arbor: UMI, 1999), 14.

${ }^{46}$ Max Brod, Israel's Music, Translated by Toni Volcani (Tel Aviv: Sefer, 1951), 35-37.

${ }^{47}$ Móricz, Jewish Nationalism, 15.
} 
ultimately unrewarding searches for specific Jewish characteristics in art." ${ }^{48}$ Ultimately, celebrating the unique life experiences of Jewish composers-rather than attempting to artificially impose unifying characteristics to their musicdispels the fallaciousness of Wagnerian racial essentialist ideology by recognizing the relative indispensability of people's unique life experiences in identity formation. As Alex Ross eloquently states:

Too many people in the past have been terrifyingly certain about what Jewish music is or should be. The Nazi campaign of destruction against the Jewish community of Europe was predicated in large measure on a description of Jewish culture. Nazi musical views drew on the writings of Richard Wagner, particularly the infamous essay "Judaism in Music," a pivotal document of modern anti-Semitism. This cataclysmic string of definitions warns us not to define. $^{49}$

The imperative not to define or categorize people or art based on the arbitrariness and inimicality of racial essentialism should be Bloch's legacy. His life shows that imposing definitions on others' identity limits the ability to truly understand people-a lesson as important today as in Bloch's lifetime.

\footnotetext{
${ }^{48}$ Matthew Baigell and Milly Heyd, eds., Complex Identities: Jewish Consciousness and Modern Art (New Brunswick: Rutgers UP, 2001), xiv.

${ }^{49}$ Alex Ross, "Does Chaos Mix With Jewish Music?” New York Times, Mar. 11, $1995,11$.
} 